\title{
Workshop Literasi Digital dalam Pembelajaran Abad 21 untuk Guru-Guru Sekolah SMP dan SMA Se-Sukabumi
}

\author{
Aswir, R Andi Ahmad Gunadi, Hasanul Misbah, Zaitun \\ Fakultas Ilmu Pendidikan Universitas Muhammadiyah Jakarta
}

\begin{abstract}
Abstrak
Literasi Digital menjadi bagian tak terpisahkan dalam Pembelajaran Abad 21, baik guru maupun peserta didik dituntut melek digital guna mendukung pembelajaran berbasis teknologi digital, khususnya pembelajaran yang memanfaatkan moda internet. Pembelajaran daring penuh (online), semi-daring (flipped), atau campuran (blended) merupakan pembelajaran berbasis moda internet. Fakta di lapangan menunjukkan bahwa masih banyak guru yang mengalami digital illiterate atau kurang terampil dalam memanfaatkan media Teknologi Informasi dan Komunikasi (TIK) untuk pembelajaran. Sementara, dunia digital saat ini banyak menawarkan platform nirbayar (freemium) yang dapat digunakan sebagai pendukung proses belajar-mengajar yang lebih efektif dan efisien. Masalah ini menjadi latar pentingnya diselenggarakan workshop literasi digital guna menjawab permasalahan tersebut sekaligus sebagai sarana pemecahan masalah yang dihadapi para guru SMP dan SMA yang berada di Kota Sukabumi dalam pemenuhan pembelajaran digital. Setelah mengikuti workshop yang dilakukan sehari penuh oleh institusi Universitas Muhammadiyah Jakarta (UMJ) dan Universitas Muhammadiyah Sukabumi (UMMI) ini, peserta mampu mempraktikkan dan mengembangkan materi pembelajaran melalui beberapa platform freemium seperti YouTube, Google Classroom, Schoology, atau media sosial seperti Facebook, Instagram dan WhatsApp, termasuk aplikasi QR (Quick Response) Code.
\end{abstract}

Kata kunci: literasi digital, guru SMP-SMA se-Sukabumi, workshop, platform freemium

\begin{abstract}
Digital literacy is defined as an integral part of 21st Century Learning, both teachers and students are required to be digital literate to support digital technology-based learning, especially in the use of the internet mode. It covers in full online learning, semi-online (flipped classroom), or mixed (blended learning). The fact that, there are still many teachers who have very limited experience in digital learning (digital illiteracy) or are less skilled in utilizing Information and Communication Technology (ICT) media for learning. Meanwhile, the digital world currently offers many free platforms (freemiums) that can be used to support a more effective and efficient teaching and learning process. This problem becomes the background for the importance of giving a digital literacy workshop to answer these problems as well as a means of solving problems faced by SMP and SMA teachers in Kota Sukabumi for fulfilling digital learning need. After participating in a full day workshop by two institutions of Universitas Muhammadiyah Jakarta (UMJ) and Universitas Muhammadiyah Sukabumi, participants were able to practice and develop learning materials through several freemium platforms such as YouTube, Google Classroom, Schoology, or social media such as Facebook, Instagram. and WhatsApp, including the QR
\end{abstract}

http://ejournal.urindo.ac.id/index.php/PAMAS

Article History :

Submitted 29 Oktober 2020, Accepted 31 Oktober 2020, Published 31 Oktober 2020 
(Quick Response) Code application.

Keywords : digital literacy, teachers of SMP-SMA in Sukabumi, workshop, freemium platform

\section{PENDAHULUAN}

Era Revolusi Industri 4.0 menggugah para guru untuk mampu beradaptasi dengan perkembangan teknologi pembelajaran. Selama ini teknologi pembelajaran masih berfokus pada penggunaan media CD, VCD atau DVD. Sementara itu perlahan ketiga perangkat digital tersebut telah ditinggalkan. Kini, dominasi Youtube sebagai media audio visual menggantikan peran ketiga piringan digital tersebut. Powerpoint telah menggantikan kapur tulis atau boardmarker. Pembelajaran blended learning mampu menyimpan materi dan dapat dipelajari pada waktu yang ditentukan.

Gambaran di atas menunjukkan bahwa literasi digital atau melek teknologi dalam pembelajaran dengan penggunaan perangkat seperti Youtube, powerpoint, dan Google Classroom telah banyak dilakukan oleh guru-guru SMP dan SMA di kota Sukabumi. Penggunaan ketiga platform gratis terbesar tersebut didasarkan pada alasan berikut. Pertama, akses dapat digunakan dengan perangkat mobile phone. Kedua, umumnya sekolah telah memiliki jaringan internet sehingga memudahkan proses penggunaan moda tersebut. Ketiga, umumnya siswa dapat mengerjakan tugas-tugas sekolah melalui moda tersebut di rumah masing-masing.

Adapun kekurangan dalam penggunaan ketiga perangkat di atas antara lain: update materi pelajaran dan soal latihan. Umumnya guru masih mengcopy-paste materi yang ada di buku cetak. Kurangnya minat siswa membuat tugas dalam bentuk video yang diunggah ke Youtube dan mengcopypaste jawaban pertanyaan yang terdapat di Google Classroom.

Menempatkan persepsi dalam pengabdian masyarakat ini didasarkan pada gagasan bahwa salah satu faktor keberhasilan yang tidak bisa diabaikan guru dalam membelajarkan siswa adalah pengetahuan tentang siswa dan karakter yang mereka miliki (Shulman, 1987, p. 8). Dan persepsi terhadap digital learning menjadi hal yang urgen dilakukan saat ini. Digitalisasi merujuk pada gabungan elemen perangkat keras (pemrosesan, memori, input dan komunikasi) dan perangkat lunak (sistem operasi dan program aplikasi) untuk melakukan berbagai tugas. Dengan demikian sumber belajar 
digital dipahami sebagai gabungan elemen perangkat keras dan lunak yang mempunyai potensi untuk mengatasi masalah belajar dan memfasilitasi kegiatan belajar (OECD, 2009, p. 31).

Pembelajaran dengan teknologi memiliki permasalahan klasik yang masih terus terjadi. Fasilitas yang kurang mendukung menjadi faktor utama dalam penentuan penggunaan teknologi dalam pembelajaran dikelas. Lemahnya koneksi internet dan fasilitas sekolah yang kurang memadai menjadi sumber alasan. Ditambah lagi, sumber daya manusia yang cenderung masih belum bisa menjawab tantangan pembelajaran berbasis teknologi. Meskipun terdapat berbagai upaya yang mungkin untuk penerapan tipe pembelajaran tersebut. Namun kurangnya kreatifitas membuat para pendidik bertumpu pada masalah fasilitas semata.

Faktanya di Kota Sukabumi Provinsi Jawa Barat, perbaikan secara perlahan terus menerus dilakukan baik dari segi fasilitas dan sumber daya manusia. Fasilitas teknologi multimedia perlahan diadakan sekolah. Dengan melakukan analisis kebutuhan, sekolahsekolah didukung oleh pemerintah mulai melakukan pengadaan media teknologi untuk pembelajaran. Kebijakan pun menuntut guru-guru untuk lebih inovatif dan oleh karena itu mulai melewati training untuk mengasah kemampuan inovasi pembelajaran. Kedua perbaikan dari sektor fasilitas dan SDM diharapkan mampu menjawab kebutuhan pendidikan anak murid.

Terdapat berbagai fasilitas fisik yang disediakan oleh sekolah-sekolah. Mulai bermunculan sekolah-sekolah yang memberikan fasilitas koneksi internet secara gratis dan berkualitas. Hal ini memudahkan praktik pembelajaran yang membutuhkan koneksi internet dikelas. Disamping itu, terdapat proyektor, laptop dan fasilitas-fasilitas fisik lainnya yang dapat dengan mudah digunakan oleh guru sekolah.

Begitu banyak pelatihan diadakan sebagai bentuk kolaborasi dengan dinas pendidikan dan universitas setempat. Pelatihan tersebut bertujuan untuk meningkatkan kualitas dan inspirasi kreativitas guru sebagai pendidik. Para guru bertemu saling bertukar pikiran dan berbagi pengalaman tentang pembelajaran dikelas. Situasi tersebut mendukung proses perkembangan performa guru dikelas. Akhirnya, mulai bermunculan pendekatan pembelajaran yang lebih dekat dengan nuansa teknologi. Seperti, penggunaan aplikasi smartphone, referensi dari internet, online test dan metode pembelajaran lainnya.

Namun tentu saja, masih banyak kendala dalam praktik pembelajaran berbasis

http://ejournal.urindo.ac.id/index.php/PAMAS 
teknologi. Pertama, banyak guru masih merasa belum terbiasa dengan penggunaan teknologi dan sebagian dari mereka masih belum menggunakan teknologi karena faktor ketidakmahiran dan kurang motivasi. Kedua, fasilitas yang disediakan terkadang mengalami kendala dan mengganggu proses pembelajaran. Bahkan, mereka beranggapan persiapan yang sudah dilakukan dengan matang bisa saja gagal karena masalah tersebut dan seringkali membuat mereka merasa kecewa dan kembali dengan metode pembelajaran yang lama. Ketiga, kebijakan belum mewajibkan dan masih belum ada arah yang jelas dari sekolah tentang penggunaan teknologi dalam pembelajaran. Hal ini membuat penanaman kultur pembelajaran baru ini tidak terasa keseriusannya dari pihak sekolah.

Dengan kondisi tersebut, tentu saja guru masih beranggapan bahwa pemanfaatan teknologi untuk pembelajaran sangat vital. Namun kondisi kontekstual dari guru sekolah di Sukabumi perlu dipaparkan secara mendalam dan dianalisa apa persepsi dan urgensi penggunaan teknologi dalam pembelajaran. Oleh karena itu, penulis ingin menginvestigasi persepsi dan urgensi digital learning bagi guru-guru sekolah SMP \& SMA se-Sukabumi.

Perkembangan tersebut membuat pergeseran paradigma Purdy dan Wright (1992), bahwa terdapat pergeseran dan perbedaan paradigma pola pembelajaran antara pembelajaran yang tidak melibatkan teknologi dengan pembelajaran yang menggunakan teknologi dan antara konsep pembelejararan di kelas (classroom setting) dengan pembelajaran terbuka atau pembelajaran digtal yang tidak harus menjalankan pembelajaran di kelas. Lebih lanjut Munir (2017), menjelaskan dalam pandangan model pembelajaran digital memiliki perbedaan dalam hal gaya mengajar, teknik serta motivasi pembelajar dam pengajar, serta model pembelajaran digital merupakan model masa depan yang efektif karena sesuai dengan tuntutan teknologi. Dalam rangka melaksanakan pembelajaran digital, ruang lingkup kompetensi bagi seorang pengajar dalam hal ini adalah guru, dalam pembelajaran digital meliputi persiapan pembelajaran terdiri dari perencanaan dan pengorganisasian pembelajaran, keterampilan penyajian baik verbal maupun non verbal, kerjasama antar tenaga pengajar, keterampilan strategi bertanya, keahlian dalam penguasaan materi pembelajaran, melibatkan pembelajar dalam pembelajaran dan koordinasi aktivitas belajarnya, pengetahuan tentang teori belajar, pengetahuan tentang pembelajaran digital, pengetahuan tentang perencanaan 
pembelajaran, dan menguasai media pembelajaran yang digunakan (Crys, 1997). Pembelajaran digitak memiliki tiga potensi menurut Kenji Kitao (1998), potensi pembelajaran digital yang dapat dimanfaatkan dalam kehidupan sehari-hari, meliputi potensi alat komunikasi, potensi alat mengkakses informasi dan potensi alat Pendidikan atau pembelajaran. Selain potensi, Munir (2017), menjelaskan pembelajaran digital memiliki fungsi sebagai fungsi suplemen pembelajar mempunyai kebebasan memilih, apakah akan memanfaatkan materi pembelajaran elektronik atau tidak, tidak ada kewajiban/keharusan bagi pembelajar untuk mengakses materi pembelajaran elektronik, kedua fungsi komplemen yaitu materi pembelajaran elektronik diprogramkan untuk melengkapi materi pembelajaran yang diterima pembelajar di dalam kelas dan ketiga fungsi substitusi yaitu pembelajar diberi beberapa alternatif model kegiatan pembelajaran, tujuannya untuk membantu mempermudah pembelajar mengelola kegiatan pembelajarannya sehingga dapat menyesuaikan waktu dan aktivitas lainnya dengan kegiatan pembelajarannya. Dari potensi dan fungsi pembelejaran digital tersebut sangat cocok untuk meningkatkan kualitas dan mengefektifkan proses pembelajaran.(Amarulloh et al., 2019)

Internet adalah media sesungguhnya dalam pendidikan berbasis $\mathrm{TI}$, karena perkembangan internet kemudian muncul model-model e-learning, distance learning, web base learning, dan istilah pendidikan berbasis TI lainnya. Internet merupakan jaringan komputer global yang mempermudah, mempercepat akses dan distribusi 8 informasi dan pengetahuan (materi pembelajaran) sehingga materi dalam proses belajar mengajar selalu dapat diperbaharui. Sudah seharusnya dalam penerapan pendidikan berbasis TI tersedia akses internet. Saat ini wilayah Indonesia yang terjangkau jaringan internet semakin meluas hal ini sebagai dampak dari perkembangan yang pesat dari jaringan telekomunikasi. Mulai dari jaringan telepon rumah/kantor, jaringan Speedy telkom, leased line ISP, sampai dengan komunikasi melalui GPRS, 3G, HSDPA dengan memanfaatkan modem GSM dan CDMA dari provider seluler adalah sederetan teknologi yang dapat digunakan untuk akses internet. Dengan kata lain, saat ini tersedia banyak pilihan teknologi untuk melakukan koneksi pada jaringan global.(Muhson, 2010)

Pembelajaran digital (digital learning) adalah sebuah istilah yang merepresentasikan berbagai strategi pendidikan yang disempurnakan dengan pemanfaatan teknologi. Pembelajaran digital mencakup blended learning, flipped 
learning, personalized learning, dan strategi lain yang mengandalkan alat digital baik pada tingkatan yang kecil maupun besar [12]. Data menunjukkan bahwa hanya dengan memberikan siswa akses ke perangkat teknologi tidak memberikan hasil yang lebih baik. Namun, integrasi teknologi yang cermat memungkinkan siswa terlibat aktif dengan gagasan mereka dan teman-temannya justru dapat meningkatkan pengalaman belajar. Hal ini menjadi tantangan bernuansa strategis yang berhubungan dengan variabel tak berwujud dan abstrak yang tak terhitung jumlahnya, antara lain perangkat elektronik, perangkat lunak, praktik di kelas, pengembangan profesional, dan kolaborasi di antara banyak pemangku kepentingan [12]. Pembelajaran digital semakin berkembang seiring dengan perkembangan teknologi. Pembelajarn digital dapat dikembangkan untuk kursus pembelajaran jarak jauh yang sepenuhnya daring, atau digabungkan dengan kelas tradisional sebagai pembelajaran campuran (blended learning) [13]. Menurut Houx [13], salah satu permasalahan paling umum dalam pembelajaran digital adalah bahwa siswa tidak terlibat dalam aktivitas daring. Ada sejumlah alasan berhubungan dengan hal ini, akan tetapi yang paling mendasar adalah siswa tidak melihat alasan untuk melakukannya. Agar siswa terlibat dalam aktivitas daring, guru (instruktur) perlu memastikan bahwa siswa memahami tugas tersebut, artinya, dan relevansinya. Dengan adanya model pembelajaran digital, para guru/ dosen/ instruktur akan lebih mudah dalam melakukan pemutakhiran bahanbahan belajar yang menjadi tanggung jawabnya sesuai dengan tuntutan perkembangan keilmuan yang mutakhir, mengembangkan diri atau melakukan penelitian guna meningkatkan wawasannya, serta mengontrol kegiatan belajar peserta didik [14]. Dalam penelitian sebelumnya, penerapan digital learning terbukti dapat meningkatkan performa dari siswa yang belajar Bahasa Inggris, dibandingkan dengan performa mereka pada tingkat prestasi yang sama seperti siswa reguler di kelas tradisional dalam pelajaran Matematika dan Membaca di kelas 3 dan 5 [15]. (Darmaningrat et al., 2018)

Pembelajaran di abad 21 harus dapat mempersiapkan generasi manusia Indonesia menyongsong kemajuan teknologi informasi dan komunikasi dalam kehidupan bermasyarakat. Pembelajaran abad 21 sebenarnya adalah implikasi dari perkembangan masyarakat dari masa ke masa. Sebagaimana diketahui bahwa masyarakat berkembang dari masyarakat primitif ke masyarakat agraris, selanjutnya ke masyarakat industri, dan sekarang bergeser ke arah masyarakat informatif. Masyarakat informatif ditandai dengan 
berkembangnya digitalisasi. Dari tahun 1960 sampai sekarang telah berkembang dengan pesat penggunaan komputer, internet dan handpone. Masyarakat telah berubah dari masyarakat offline menjadi masyarakat on line. Sebagai catatan pengguna internet di Indonesia pada tahun 2015 sebanyak 88,1 juta orang telah meningkat menjadi sebanyak 132,5 juta orang. Oleh karena perkembangan digitalisasi yang semakin pesat di masyrakat, mau tidak mau pembelajaran di sekolah di Indonesia harus mengikuti perkembangan tersebut. (Syahputra, 2018)

\section{METODE}

Pada dasarnya, kegiatan pengabdian masyarakat melibatkan 13 guru sekolah SMP \& SMA di Sukabumi dan menginvestigasi implementasi kegiatan pembelajaran berbasiskan teknologi. Kegiatan diawali oleh pemateri (penulis) dengan mempresentasikan konsep dan praktik penggunaan teknologi untuk pembelajaran. Lalu, diadakan sesi tanya jawab untuk berbagi pengalaman dan diakhir diskusi menawarkan berbagai solusi terhadap permasalahan yang dihadapi dalam pembelajaran berbasis teknologi.

Para peserta juga diminta untuk mengisi kuesioner dalam bentuk GoogleForm untuk secara komprehensif menggambarkan konteks permasalahan yang dihadapi oleh peserta. Data interview (interaksi dikelas) dan data kuesioner (GoogleForm) dianalisis untuk dapat mendeskripsikan persepsi dan urgensi digital literasi guru-guru sekolah SMP \& SMA di Sukabumi.

JADWAL

\begin{tabular}{|c|c|c|c|}
\hline \multirow{2}{*}{ No } & \multirow{2}{*}{ Nama Kegiatan } & \multicolumn{2}{|c|}{2020} \\
\hline & & Januari & Februari \\
\hline 1 & $\begin{array}{l}\text { Presentasi Persepsi \& Urgensi Digital } \\
\text { Learning pada Guru-Guru Sekolah SMP } \\
\text { \& SMA se-Sukabumi }\end{array}$ & & \\
\hline 2 & $\begin{array}{l}\text { Pengambilan Data Kuesioner \& } \\
\text { Interview }\end{array}$ & & \\
\hline 3 & Analisis Data & & \\
\hline 4 & $\begin{array}{l}\text { Pengumpulan Laporan Pengabdian } \\
\text { Masyarakat }\end{array}$ & & \\
\hline
\end{tabular}


Jurnal Pelayanan dan Pengabdian Masyarakat (PAMAS) 


\section{HASIL DAN PEMBAHASAN}

Setelah diawali pembukaan secara resmi oleh Dekan Fakultas Keguruan dan IImu Pendidikan Universitas Muhammadiyah Sukabumi, acara workshop dimulai dengan pengisian kuesioner dalam bentuk Googleform oleh peserta workshop untuk mendapatkan gambaran secara komprehensif mengenai konteks permasalahan yang dihadapi oleh peserta dalam literasi digital. Data interview (interaksi di kelas) dan data kuesioner (Googleform) dianalisis untuk dapat mendeskripsikan hasil pengabdian masyarakat tentang literasi digital guru-guru sekolah SMP dan SMA di kota Sukabumi.

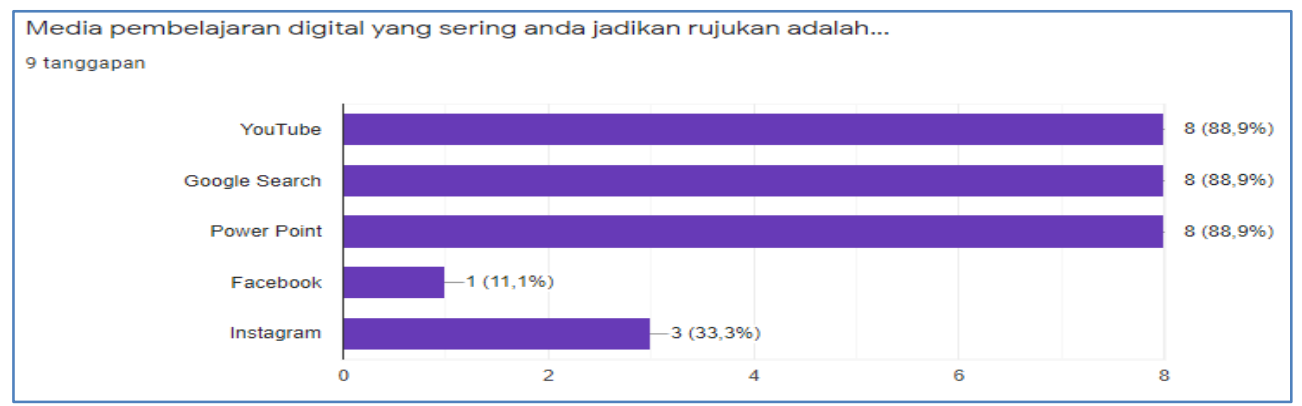

Berdasarkan hasil kuesioner di atas, para peserta, guru-guru sekolah SMP dan SMA, sangat sering memanfaatkan media Youtube, Google Search, dan PowerPoint. Sementara dalam penggunaan media sosial seperti Facebook dan Instagram masih sangat sedikit.

Tabel 2. Indikator Pencapaian Workshop

\begin{tabular}{|c|l|c|}
\hline No & \multicolumn{1}{|c|}{ Materi/Praktik } & Keterangan \\
\hline 1 & Literasi Digital & tuntas \\
\hline 2 & Asesmen Digital: Kahoot dan Quizizz & tuntas \\
\hline 3 & Model Pembelajaran Abad 21 & tuntas \\
\hline 4 & QR Code dan Media Sosial & tuntas \\
\hline
\end{tabular}

Kegiatan Workshop Literasi Digital dalam Pembelajaran Abad 21 secara umum telah berlangsung dengan baik dan lancar (lihat Tabel 2). Kegiatan ini meliputi kegiatan awal yaitu presentasi oleh pemateri dengan memaparkan konsep literasi digital, model pembelajaran abad 21 dan dilanjutkan dengan praktik penggunaan teknologi digital untuk pembelajaran 
berupa platform online termasuk media sosial, dan QR Code. Lalu, diadakan sesi tanya jawab untuk berbagi pengalaman dan diakhiri dengan menawarkan berbagai solusi terhadap permasalahan yang dihadapi dalam pembelajaran berbasis teknologi.

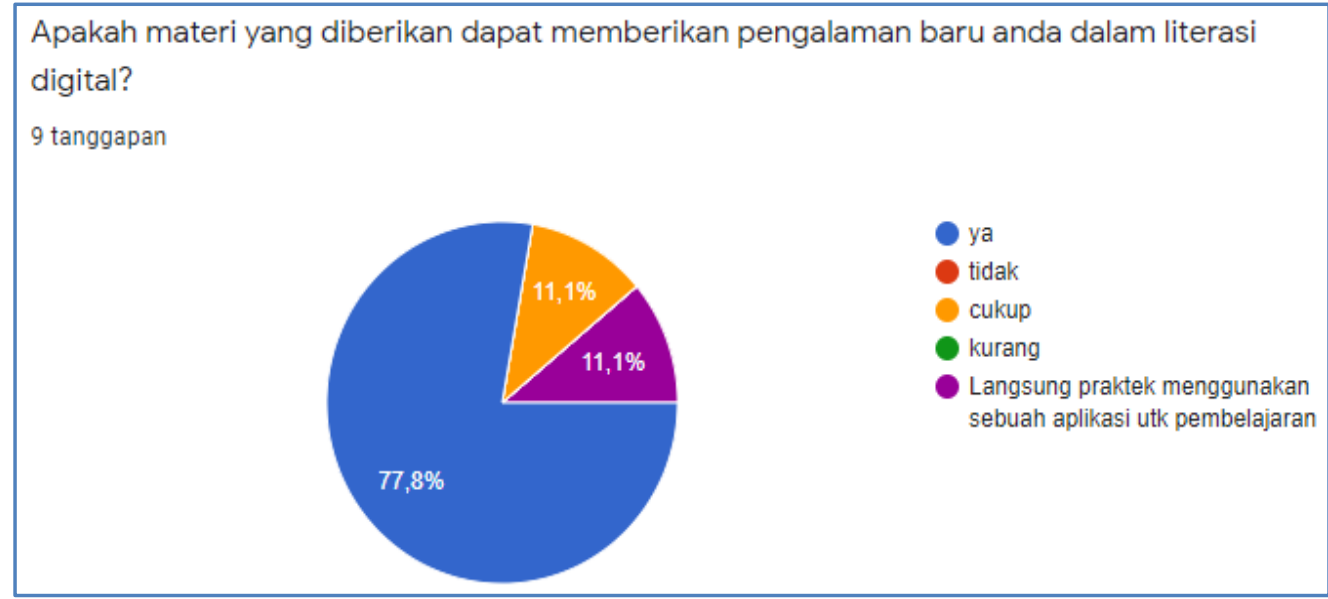

Dari pie diagram di atas, dapat dijelaskan bahwa mayoritas peserta workshop mendapatkan pengalaman baru dalam literasi digital. Peserta sepakat untuk secara kontinyu mempraktikkan pembelajaran digital dalam proses belajar mengajar. Hal ini sesuai dengan testimoni sebagian peserta yang telah menggunakan beberapa platform pembelajaran pada mata pelajaran yang mereka ampu. Platform PowerPoint sangat dominan digunakan peserta dalam pembelajaran

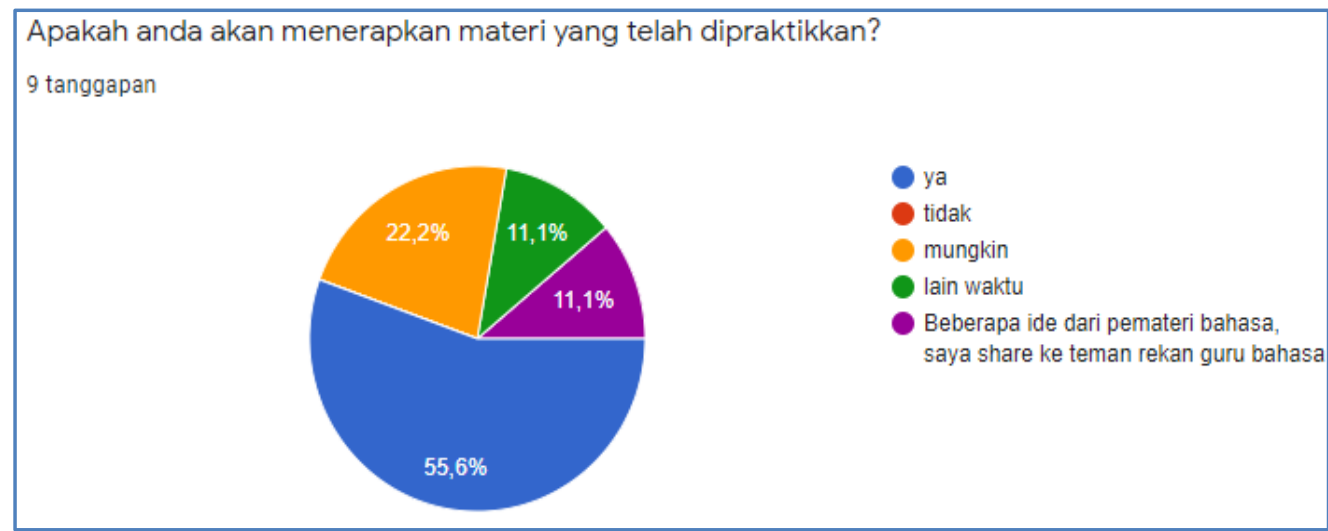

Bagi para peserta pelatihan yang telah dilakukan dapat mengembangkan profesionalisme dan performa pembelajaran di kelas. Diharapkan pelatihan tersebut dapat membekali baik secara akademis maupun praktis. Pelatihan yang benar-benar dibutuhkan sebaiknya lebih kontekstual dengan permasalahan yang dihadapi oleh guru. Praktikalitas dari pelatihan sangat dibutuhkan sehingga problem solving terhadap situasi yang dihadapi terpenuhi. 
Dalam sesi praktik, peserta tidak terlalu mengalami kesulitan dalam mencoba mengaplikasikan beberapa platform. Diagram di bawah ini juga menjelaskan peserta lebih termotivasi untuk mencobanya.

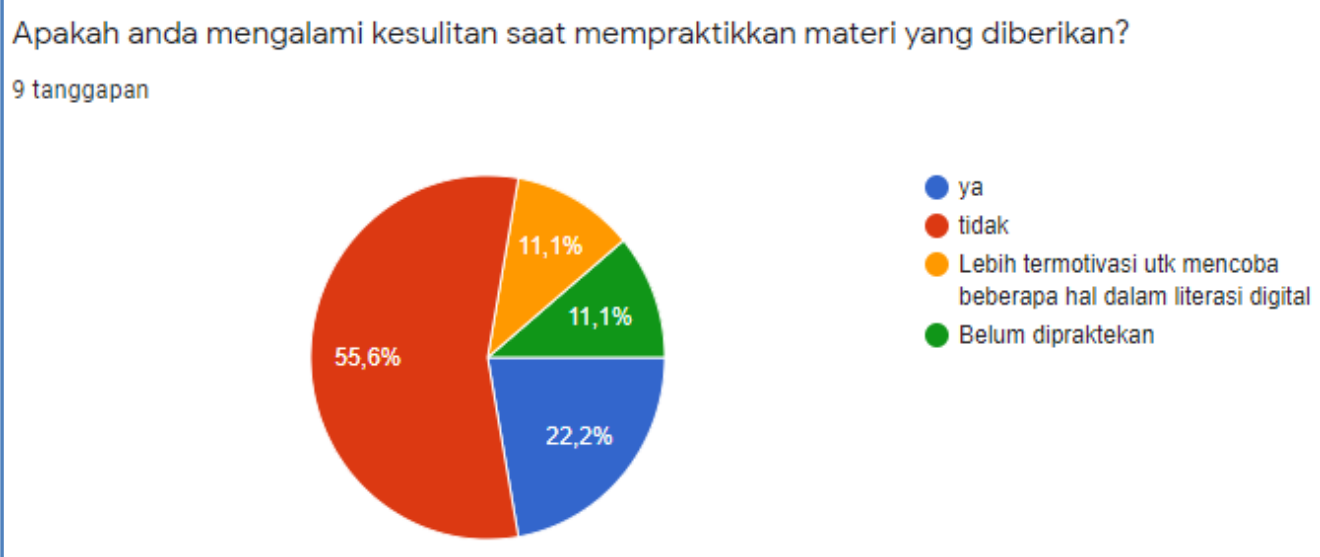

Karena ada diantara beberapa peserta yang memang baru mengetahui penggunaan platform seperti QR Code, media sosial, dan platform asesmen seperti Kahoot dan Quizizz.

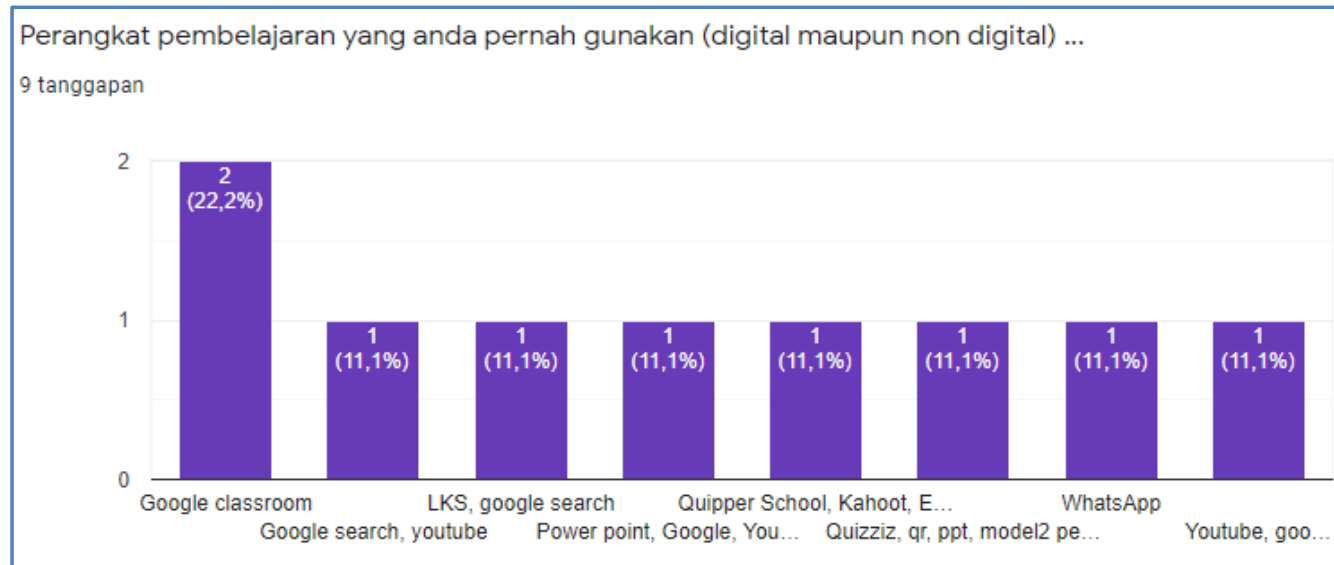

Umpan balik dari pelatihan sehari pada guru berbagai bidang studi ini dapat digambarkan pada pie diagram di bawah ini.

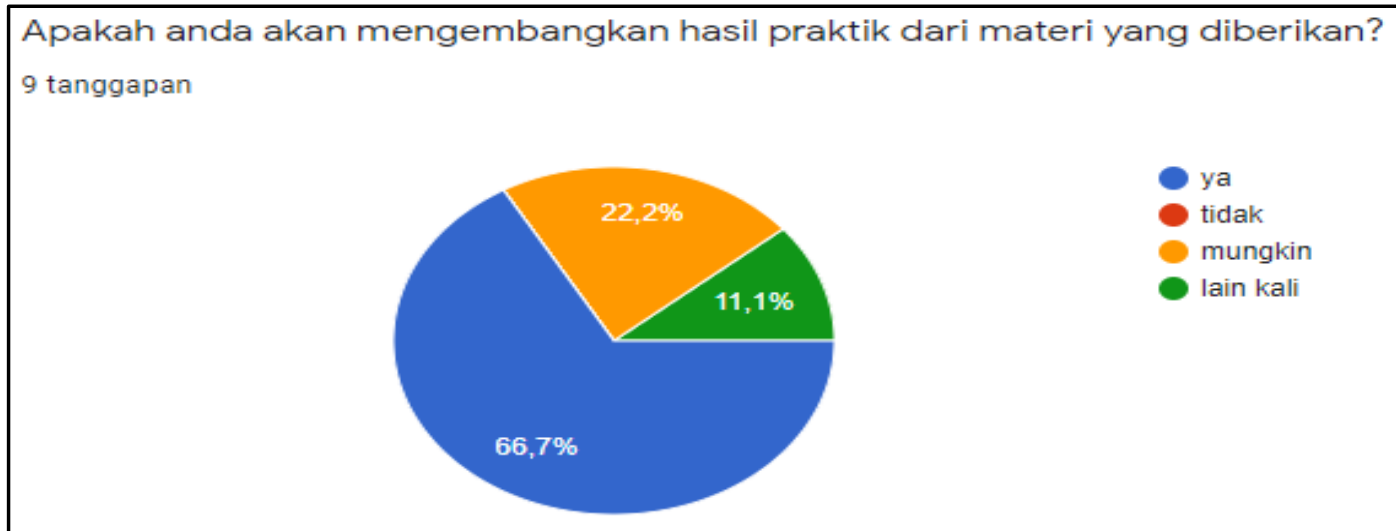


Secara umum peserta worshop akan mengembangkan materi pembelajaran di YouTube dengan membuat video pembelajaran sendiri. Kemudian pada guru mata pelajaran Sains, pengembangan QR Code menjadi hal yang sangat baru. Selanjutnya usulan pemateri kepada peserta workshop agar dapat memaksimalkan media sosial sebagai media pelengkap pembelajaran akan menjadi pekerjaan rumah tersendiri. Mayoritas peserta akan melaksankaan penggunaan sosial media sebagai sarana dan

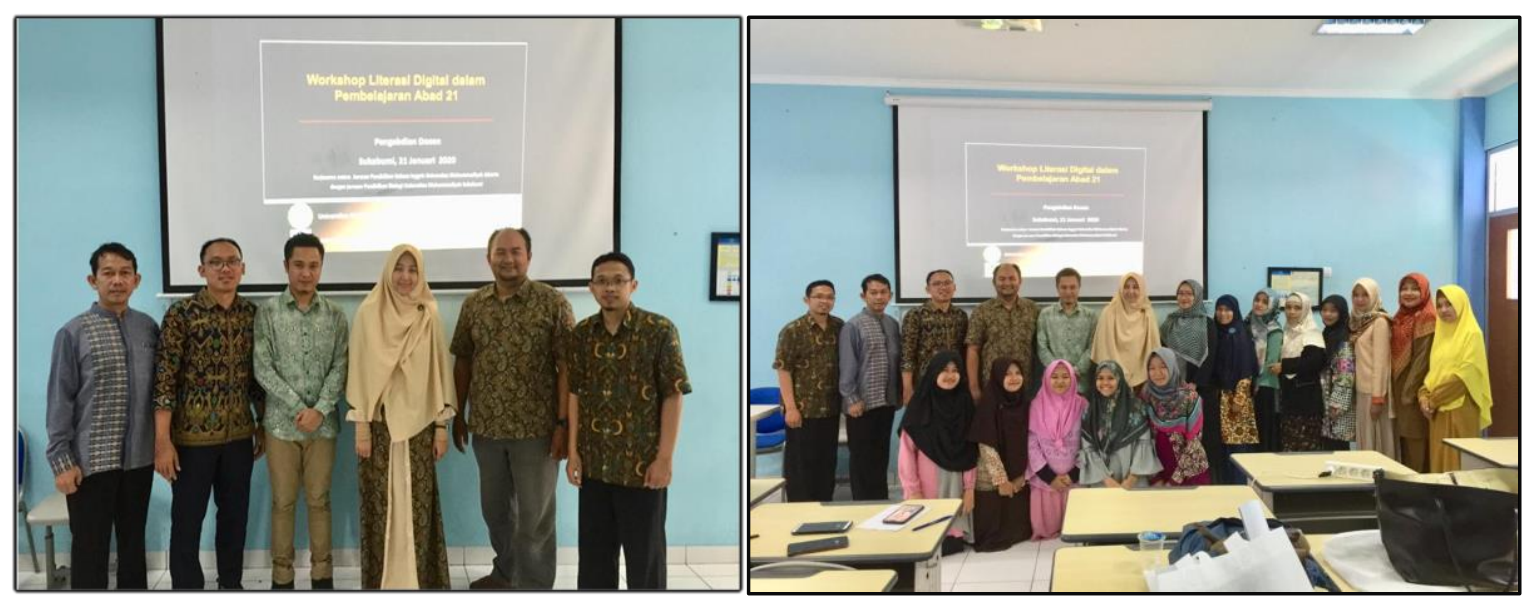

sumber belajar.

Gambar 1. Pemateri bersama Dekan FKIP UMMI

Gambar 2. Pemateri dan Peserta

Gambar 3. Tim Pengabdian Masyarakat FIP UMJ

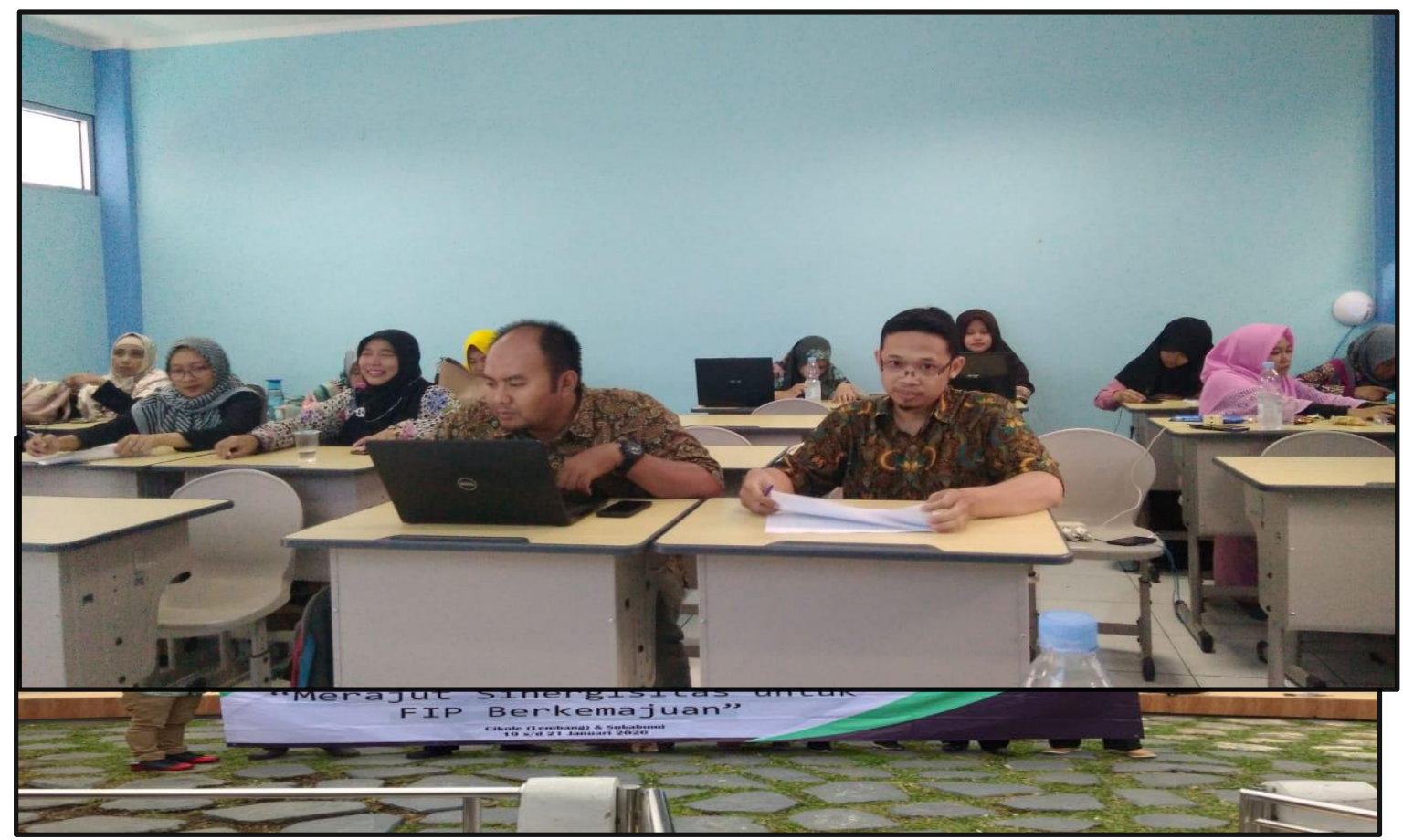

Gambar 4. Suasana Pelatihan 


\section{SIMPULAN}

Pelatihan atau workshop literasi digital yang telah dilakukan selama satu hari penuh ini menghasilkan beberapa rekomendasi sebagai berikut: 1) Para peserta ingin melanjutkan pelatihan ini dalam bentuk pengembangan konten secara mandiri dalam bentuk video yang diupload ke YouTube, pembuatan QR Code mensinkronisasikan platform Google Classroom dengan asesmen berupa Kahoot dan Quizizz serta PowerPoint interaktif; 2) Para peserta akan menggunakan hasil pelatihan ini dengan mempraktikkan penggunaan berbagai media digital yang telah dipelajari sebagai model pembelajaran campuran (blended learning). Secara keseluruhan peserta merespon positif kegiatan pengabdian ini dan diharapkan ada kelanjutan pelatihan berupa pembuatan materi animasi dan otensitas materi yang akan dikembangkan dalam bentuk digital.

\section{UCAPAN TERIMAKASIH}

Tim Pengabdian Masyarakat dari kedua institusi, FIP UMJ dan FKIP UMMI Sukabumi mengucapkan terimakasih yang tak terhingga kepada pimpinan dan staf atas terselenggaranya kegiatan dharma keempat di perguruan tinggi yang bernaung dalam Persyarikatan Muhammadiyah ini. Kepada para peserta, perwakilan bapak dan ibu guru SMP dan SMA yang berada di Kota Sukabumi, kami haturkan terimakasih yang sebesarbesarnya atas dukungan dan partisipasi aktifnya pada kegiatan pelatihan ini.

\section{DAFTAR PUSTAKA}

1. Amarulloh, A., Surahman, E., \& Meylani, V. (2019). Refleksi Peserta Didik Terhadap Pembelajaran Berbasis Digital. Metaedukasi, 1(1), 13-23.

2. Darmaningrat, E. W. T., Ali, A. H. N., Wibowo, R. P., \& Astuti, H. M. (2018). Pemanfaatan Aplikasi Digital Learning Untuk Pembelajaran Pengayaan Di Sekolah Menengah Kota Surabaya. Seminar Nasional Sistem Informasi Indonesia, November, 85-95. http://is.its.ac.id/pubs/oajis/index.php/file/download_file/1828

3. Muhson, A. (2010). Pengembangan Media Pembelajaran Berbasis Teknologi Informasi. Jurnal Pendidikan Akuntansi Indonesia, 8(2). https://doi.org/10.21831/jpai.v8i2.949

4. Syahputra, E. (2018). Pembelajaran Abad 21 Dan Penerapannya Di Indonesia. Prosiding Seminar Nasional SINASTEKMAPAN, 1(March), 1276-1283. 
Jurnal Pelayanan dan Pengabdian Masyarakat (PAMAS)

https://www.researchgate.net/publication/331638425_PEMBELAJARAN_ABAD_21_DA

N_PENERAPANNYA_DI_INDONESIA/link/5c847e51458515831f96f565/download 